\title{
Induction of Antiviral Responses by Acibenzolar-S-Methyl Against Cucurbit chlorotic yellows virus in Melon
}

\author{
Minoru Takeshita, Mitsuru Okuda, Shiori Okuda, Ayaka Hyodo, Kaori Hamano, Naruto Furuya, and Kenichi Tsuchiya \\ First, fourth, sixth, and seventh authors: Laboratory of Plant Pathology, Faculty of Agriculture, Kyushu University, 6-10-1 Hakozaki, \\ Higashi-ku, Fukuoka 812-8581, Japan; second author: Ministry of Agriculture, Forestry and Fisheries, Tokyo, 100-8950, Japan; third \\ author: The United Graduate School of Agricultural Sciences, Kagoshima University, Kagoshima, 890-0065, Japan; and fifth author: \\ Japan Tobacco INC. Leaf Tobacco Research Center, Tochigi, 323-0808, Japan.
}

Accepted for publication 16 April 2013.

\begin{abstract}
Takeshita, M., Okuda, M., Okuda, S., Hyodo, A., Hamano, K., Furuya, N., and Tsuchiya, K. 2013. Induction of antiviral responses by acibenzolar-S-methyl against Cucurbit chlorotic yellows virus in melon. Phytopathology 103:960-965.

Cucurbit chlorotic yellows virus (CCYV) (family Closteroviridae, genus Crinivirus) is an emerging virus which causes severe diseases on melon (Cucumis melo) plants. CCYV-infected melon plants display yellowing, mottling, chlorosis, or chlorotic spots on leaves. To develop a

boxylic acid-S-methyl-ester (ASM) to suppress CCYV infection was evaluated. ASM treatment on melon plants greatly increased the expression levels of pathogenesis-related 1a gene, a marker gene for systemic acquired resistance. ASM treatment on melon plants before inoculation of CCYV suppressed systemic symptoms and decreased CCYV accumulation. ASM treatment on melon even after inoculation of CCYV reduced disease severity and accumulation levels of CCYV. The results show the potential for ASM treatment on attenuation of the CCYV disease symptoms.
\end{abstract} new control strategy, the potential for 1,2,3-benzothiadiazole-7-thiocar-
Cucurbit chlorotic yellows virus (CCYV) (family Closteroviridae, genus Crinivirus) first emerged in Kumamoto Prefecture in the southwest of Japan (21). To date, from 2004 onward, melon (Cucumis melo) plants with chlorotic yellows were observed in geographically distinct regions in Japan. Furthermore, occurrence of CCYV and losses of yield have been reported in cucurbit plants in Taiwan, China, and Sudan $(7,9,11)$. Okuda et al. (21) showed efficient vectoring of CCYV to melon by Bemisia tabaci biotype $\mathrm{Q}$ whitefly, and proposed CCYV as a new member of the genus Crinivirus in the family Closteroviridae $(10,30)$. CCYV is becoming a considerable threat to melon production in both greenhouses and open-fields in Japan (21). Populations of B. tabaci biotype $\mathrm{Q}$, which is resistant to pyrethroids, might be facilitating the rapid spread of CCYV in Japan $(8,21)$. Although some insecticides such as nitenpyram are currently effective, measures that deeply rely on a few insecticides might be hampered when $B$. tabaci biotype Q populations develop further insecticide resistance. Thus far, genetic sources that are available to develop CCYV-resistant cultivars are limited (22). In addition, insectproof nets with fine mesh size cause reduced ventilation, which is unfavorable for plant growth in a greenhouse. Thus, it is imperative to develop an alternative strategy for effective control of CCYV.

Some synthetic chemicals in use for disease control increase plant immunity against a broad spectrum of pathogens. These chemical compounds are well known as plant defense activators which can stimulate signal transduction pathways associated with systemic acquired resistance (SAR) (27). In general, chemically induced host resistance is expressed systemically for several weeks.

Corresponding author: M. Takeshita; E-mail address: minorutk@agr.kyushu-u.ac.jp

* The $\boldsymbol{e}$-Xtra logo stands for "electronic extra" and indicates that the online version contains two supplementary figures and two supplementary tables.

http://dx.doi.org/10.1094/PHYTO-08-12-0188-R

(C) 2013 The American Phytopathological Society
The aim of this study was to evaluate the potential of chemically induced host resistance against CCYV infection. The best-studied plant defense activator, 1,2,3-benzothiadiazole-7-thiocarboxylic acid-S-methyl-ester (common name: acibenzolar-S-methyl [ASM]), which is also called benzothiadiazole (BTH), was of great value to induce systemic resistances against a wide range of plant pathogens, including several plant viruses $(2,4,12,16,23,24,28)$. Molecular analyses by Friedrich et al. (5) revealed that BTH activates a basal host defense which is similar to salicylic acid (SA)induced SAR. Lawton et al. (13) reported that expression levels of the gene encoding pathogenesis-related $(P R)$ protein 1 provide a useful molecular marker for BTH-induced host resistance. We report significant activation of the PRla gene expression in melon by ASM. We further report promising effects of ASM treatment on attenuation of the CCYV disease syndrome in melon.

\section{MATERIALS AND METHODS}

Plant and inoculation sources. $C$. melo 'Earl's Seinu' melons were used in this study. The CCYV isolate used originated from Kumamoto Prefecture, Japan (21), and was maintained on cucumber (C. sativus 'Shimoshirazu-Jibai') through transmission by whiteflies (B. tabaci biotype Q). Cucumber plants infected with CCYV were kept in a cage with insect proof nets $(\approx 2 \mathrm{~m}$ on a side) in a glasshouse (inoculation cage) and were used as the inoculum source.

Virus inoculation and ASM treatment. In preliminary experiments, melon sprayed with ASM (active ingredient: $50 \mu \mathrm{g} / \mathrm{ml} ; 5 \%$ wt/wt) (Syngenta Japan K. K.) at $>50 \mathrm{ppm}$ showed chlorotic spots and stunting (unpublished data). In subsequent experiments, ASM dissolved in distilled water was used at the concentrations of 2.5, 10 , or $25 \mathrm{ppm}$. For challenge inoculation of CCYV, ASM solution was sprayed onto all the leaves of the first- to second-true-leaf stage melon seedlings for $5 \mathrm{~s}$ per plant using a handheld garden sprayer (BH-566-R; National, Japan). After 3 days, the seedlings were transferred to the inoculation cage, in which whiteflies 
(B. tabaci biotype Q) were kept on CCYV-infected cucumber plants as the inoculum source, and sprayed plants were exposed to the whiteflies for 3 days. During the assays, melon seedlings were infested by the whiteflies with a population of 20 to 30 individuals per leaf. Whiteflies were killed by spraying the plants with nitenpyram $(50 \mathrm{ppm})$ after virus inoculation. For challenge treatment of ASM, the second- to third-true-leaf stage melon seedlings were first exposed to the $B$. tabaci biotype $\mathrm{Q}$ for 3 days, whiteflies were killed by spraying the nitenpyram (50 ppm), and then ASM was applied to the whole seedlings. The seedlings were transferred to a pot $(12 \mathrm{~cm}$ in diameter) and maintained in a greenhouse for $\approx 1$ month.

Evaluation of symptom severity. Symptom severity was evaluated by observing symptoms on all leaves, as described by Gyotoku et al. (8). The rating of symptoms was as follows: 0, no symptoms; 1, slight mottling; 2, <20\% leaf area with yellows; 3 , 20 to $50 \%$ leaf area with yellows; and $4,>50 \%$ leaf area with yellows. Symptom severity was calculated in each plant by the formula $\mathrm{D}=\left[\Sigma\left(d_{\mathrm{i}}\right) / n / 4\right] \times 100$, where $\mathrm{D}$ is symptom severity of a plant, $d_{\mathrm{i}}$ is symptom rate of $i$ th leaf, $n$ is the number of leaves, and 4 is the rating scale from 1 to 4 . In all, 6 to 16 replicates were tested for each treatment.

Detection of CCYV RNA and PRIa mRNA by reverse-transcription quantitative polymerase chain reaction. Minimum information for reverse-transcription quantitative polymerase chain reaction (RT-qPCR) experiments is described in Supplementary Table 1, according to Bustin et al. (3). Total RNA samples were prepared from melon plants with RNAiso Plus (TaKaRa, Japan) according to the manufacturer's instructions. Leaf samples were taken from two different leaves at lower, intermediate, or upper positions of each plant (e.g., two leaves at the intermediate positions which were third and fourth up from the leaf treated with ASM). For synthesis of the first-strand cDNA of CCYV RNA1, primer CCYV-RNA1-RT1 was designed based on the complementary sequence of nucleotides 1,758 to 1,779 of CCYV RNA 1 (accession number AB523788). All the primers used are listed in Supplementary Table 2. First-strand cDNA was synthesized using total RNA (100 to $10 \mathrm{ng}$ ), CCYV-RNA1-RT1 primer, oligo-d(T) primer, and the ReverTraAce qPCR RT Kit (TOYOBO, Japan). Total RNA was heat denatured at $75^{\circ} \mathrm{C}$ for 5 min and cooled on ice before adding to a reaction mixture. RT was performed in the reaction mixture $(10 \mu \mathrm{l})$ containing nuclease-free water, $2 \mu \mathrm{l}$ of $5 \times$ RT buffer, $0.5 \mu \mathrm{l}$ of RT Enzyme Mix, $1 \mu \mathrm{l}$ of CCYV-RNA1-RT1 ( $5 \mathrm{pmol} / \mu \mathrm{l}), 1 \mu \mathrm{l}$ of Oligo-d(T) primer $(5 \mathrm{pmol} / \mu \mathrm{l})$, and $1 \mu \mathrm{l}$ of total RNA. The mixture was incubated at $42^{\circ} \mathrm{C}$ for $90 \mathrm{~min}$.

For qPCR amplification, $1 \mu \mathrm{l}$ of the synthesized cDNA and the primers CCYV-RNA1-F1 and CCYV-RNA1-R1 (22), C.meloPR1a-F and C.melo-PR1a-R, or C.melo-actin-F and C.meloactin-R (22) were added to a tube containing a qPCR mixture. CCYV-RNA1-F1 and CCYV-RNA1-R1 were used for detection of positive-sense CCYV RNA1. C.melo-PR1a-F and C.meloPR1a-R were used for detection of the PRla gene of $C$. melo (accession number AB698860). C.melo-actin-F and C.melo-actin$\mathrm{R}$ were used to amplify the actin gene of $C$. melo (accession number AB640865) for normalization according to Okuda et al. (22). Reaction mixtures were prepared using THUNDERBIRD SYBR qPCR Mix (TOYOBO) according to manufacturer's recommended procedure. The following additions were made to each reaction: $7 \mu \mathrm{l}$ of nuclease-free water, $10 \mu \mathrm{l}$ of THUNDERBIRD SYBR qPCR Mix, $1 \mu \mathrm{l}$ of forward primer, $1 \mu \mathrm{l}$ of reverse primer, and $1 \mu \mathrm{l}$ of cDNA mixture. qPCR was conducted on the Thermal Cycler Dice RealTime System Single TP850 (TaKaRa) with a 96well reaction block. The qPCR mixtures were incubated at $95^{\circ} \mathrm{C}$ for $1 \mathrm{~min}$ followed by 40 cycles of $95^{\circ} \mathrm{C}$ for $10 \mathrm{~s}, 60^{\circ} \mathrm{C}$ for $30 \mathrm{~s}$, and $72^{\circ} \mathrm{C}$ for $20 \mathrm{~s}$. Threshold cycles (Cts) were determined using Thermal Cycler Dice RealTime System Single Software (TaKaRa) for all samples. Ct values obtained from dilution series of the
cDNA copy of candidate genes, including the corresponding region, were used by Thermal Cycler Dice RealTime System Single Software package to plot a standard curve. PCR efficiency was calculated by performing the standard curves. PCR efficiency and $R^{2}$ value were $>91.4 \%$ and 0.996 , respectively. The melting curves of the PCR products were monitored at 60 to $95^{\circ} \mathrm{C}$ to confirm the specificity of amplification. Relative quantification of PRla mRNA and viral RNA concentrations was calculated according to the $\Delta \Delta \mathrm{Ct}$ method (25) using the actin gene mRNA values and RNA of healthy melon plants as references. The actin gene was used as an internal control after the evaluation of stability of four reference candidate genes (Supplementary Figures 1 and 2; Supplementary Table 2) $(6,22,26,29)$. Five to eight biological replicates and three technical replicates were used for each assay. The detection assay was repeated once.

\section{RESULTS}

Kinetics of ASM-induced host resistances. To examine ASMinduced host resistances in different leaf-tissues, melon plants at the first-true-leaf stage were sprayed with ASM (active ingredient: $25 \mu \mathrm{g} / \mathrm{ml}, 25 \mathrm{~A}$ ) under greenhouse conditions. Expression levels of the PRla gene in the ASM-treated first true leaves and the nontreated fourth upper leaves of melon, which were not developed when ASM was applied, were measured at 2 weeks posttreatment (wpt) (Fig. 1). Relative expression levels of the $P R l a$ gene in the ASM-treated leaves were higher than those in the upper, nontreated leaves. Significant induction of PRla gene expression was not observed in water-treated (mock) plants. The results suggested that ASM-mediated host PRla expression is induced systemically but is stronger in the ASM-treated sites. Melon plants sprayed with $25 \mathrm{~A}$ exhibited slight stunting, and fewer local necrotic spots within 2 to $3 \mathrm{wpt}$, then grew without progressive phytotoxicity.

Effects of ASM treatment on induction of resistance to CCYV. To evaluate disease incidence and analyze relative accumulation of CCYV, melon plants were treated with ASM before or after inoculation of CCYV.

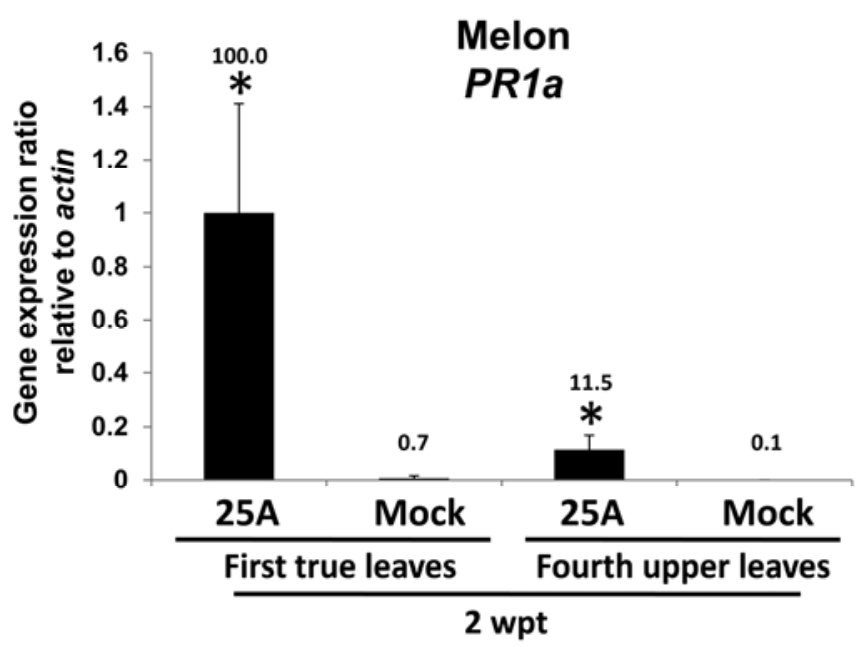

Fig. 1. Relative expression levels of the pathogenesis-related $(P R) 1 a$ gene in the acibenzolar-S-methyl (ASM)-treated and -nontreated leaf tissues of melon plants. Plants were treated with ASM at a concentration of $25 \mathrm{ppm}(25 \mathrm{~A})$. A set of five plants per treatment was used for the detection assay. Leaf samples were harvested at 2 weeks posttreatment (wpt). Expression levels of the PRIa gene in melon were measured by quantitative reverse-transcription polymerase chain reaction. Expression levels (in arbitrary units) show mean \pm standard error for samples corresponding to the individual plants. An asterisk denotes a significant difference $(P<0.05)$ between the 25A-treated and the watertreated (mock) leaves, according to Student's $t$ test. Numerical indication (\%) showed relative levels to the highest of those of PRla gene expression (100\%). 
The water-treated (mock) and CCYV-inoculated plants first showed characteristic symptoms on leaves at lower positions at 3 to 4 weeks postinoculation (wpi). On the other hand, plants sprayed with $25 \mathrm{~A}$ exhibited a considerably delayed symptom development or no clear symptoms until 4 wpi; treatment with $25 \mathrm{~A}$ at 3 days before inoculation (25A-3dbi) effectively reduced disease severity (Tables 1 and 2) and, even in the $25 \mathrm{~A}$ treatment at 3 days postinoculation (25A-3dpi), the disease incidence was reduced significantly (Tables 2 and 3 ).

Real-time RT-PCR using total RNA extracted from the mocktreated plants revealed that CCYV accumulated more in the lower leaves than in the upper leaves (Fig. 2). In contrast, the $25 \mathrm{~A}-3 \mathrm{dbi}$ plants showed a significant decrease in the accumulation levels of
CCYV (Fig. 2A). Many of the 25A-3dbi plants (12/14, 85.7\%) grew without symptoms. Furthermore, the 25A-3dpi plants exhibited reduced levels of CCYV in the lower and intermediate leaves (Fig. 2B). These results suggested that ASM could be effective to reduce accumulation or infection by CCYV, and also decreased the symptom severity or delayed the development of systemic symptoms, even after establishment of CCYV infection in melon plants.

Induction of PRIa expression in ASM-treated plants inoculated with CCYV. To clarify whether the ASM-induced antiviral responses correlate with decreases in CCYV, the kinetics of PRla expression and CCYV levels were analyzed during the course of virus infection in melon plants treated with ASM before virus

TABLE 1. Disease severity on melon leaves treated with acibenzolar-S-methyl (ASM) before inoculation with Cucurbit chlorotic yellows virus

\begin{tabular}{|c|c|c|c|c|c|c|c|c|c|c|c|c|c|c|c|c|}
\hline \multirow[b]{3}{*}{ Position $^{\mathrm{a}}$} & \multicolumn{16}{|c|}{ Plants ${ }^{b}$} \\
\hline & \multicolumn{8}{|c|}{ ASM-treated replicates } & \multicolumn{8}{|c|}{ Mock-treated replicates } \\
\hline & 1 & 2 & 3 & 4 & 5 & 6 & 7 & 8 & 1 & 2 & 3 & 4 & 5 & 6 & 7 & 8 \\
\hline \multicolumn{17}{|l|}{$\overline{\text { Upper }}$} \\
\hline 8 & $\mathbf{0}$ & $\mathbf{0}$ & $\mathbf{0}$ & $\mathbf{0}$ & $\mathbf{0}$ & $\mathbf{0}$ & $\mathbf{0}$ & $\mathbf{0}$ & $\mathbf{0}$ & $\mathbf{0}$ & 1 & $\mathbf{0}$ & $\mathbf{0}$ & $\mathbf{0}$ & $\mathbf{0}$ & $\mathbf{0}$ \\
\hline 7 & $\mathbf{0}$ & $\mathbf{0}$ & $\mathbf{0}$ & $\mathbf{0}$ & $\mathbf{0}$ & $\mathbf{0}$ & $\mathbf{0}$ & $\mathbf{0}$ & $\mathbf{0}$ & $\mathbf{0}$ & 1 & $\mathbf{0}$ & 0 & 0 & $\mathbf{0}$ & $\mathbf{0}$ \\
\hline \multicolumn{17}{|c|}{ Intermediate } \\
\hline 6 & 0 & 0 & 0 & 0 & 0 & 0 & 0 & 0 & 1 & 1 & 1 & 1 & 0 & 0 & 0 & 0 \\
\hline 5 & 0 & $\mathbf{0}$ & 0 & 0 & 0 & $\mathbf{0}$ & 0 & 0 & 1 & 1 & 1 & 1 & 0 & 0 & 1 & 0 \\
\hline 4 & $\mathbf{0}$ & $\mathbf{0}$ & $\mathbf{0}$ & $\mathbf{0}$ & $\mathbf{0}$ & $\mathbf{0}$ & $\mathbf{0}$ & $\mathbf{0}$ & 4 & 3 & 3 & 3 & $\mathbf{0}$ & 3 & 1 & 1 \\
\hline 3 & 0 & 0 & 0 & 0 & 0 & 0 & 0 & 1 & 4 & 4 & 4 & 4 & 3 & 3 & 2 & 2 \\
\hline \multicolumn{17}{|l|}{ Upper } \\
\hline 2 & $\mathbf{0}$ & 3 & $\mathbf{0}$ & $\mathbf{0}$ & $\mathbf{0}$ & $\mathbf{0}$ & 0 & 0 & 4 & 4 & 4 & 4 & 3 & 4 & 2 & 2 \\
\hline 1 & $\mathbf{0}$ & 0 & 0 & 0 & 0 & 0 & 0 & 1 & 4 & 4 & 4 & 4 & 3 & 4 & 2 & 2 \\
\hline & 0.0 & 9.4 & 0.0 & 0.0 & 0.0 & 0.0 & 0.0 & 6.3 & 56.3 & 53.1 & 59.4 & 53.1 & 28.1 & 43.8 & 25.0 & 21.9 \\
\hline
\end{tabular}

a Leaf samples from lower, intermediate, and upper positions in bold were analyzed by quantitative reverse-transcription polymerase chain reaction in Figure 2 A.

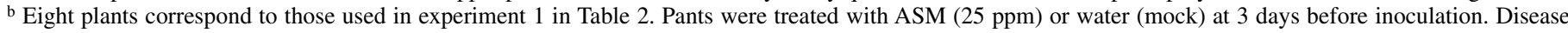
severity (leaf positions 1 to 8 ) was calculated by the formula $\mathrm{D}=\left[\Sigma\left(d_{\mathrm{i}}\right) / n / 4\right] \times 100$, as described in the text.

TABLE 2. Effect of acibenzolar-S-methyl (ASM) on Cucurbit chlorotic yellows virus (CCYV) disease severity in melon under greenhouse conditions

\begin{tabular}{|c|c|c|c|c|}
\hline \multirow[b]{2}{*}{ Treatment } & \multicolumn{4}{|c|}{ Experiment $^{\mathrm{a}}$} \\
\hline & 1 & 2 & 3 & 4 \\
\hline ASM-CCYV & $2.0 \pm 1.3^{*}$ & $\ldots$ & $25.0 \pm 13.2 *$ & \\
\hline CCYV-ASM & $\ldots$ & $20.3 \pm 4.9^{*}$ & $\ldots$ & $14.1 \pm 3.2 *$ \\
\hline CCYV-Mock ${ }^{\mathrm{d}}$ & $42.6 \pm 5.4$ & $40.7 \pm 5.2$ & $64.1 \pm 1.8$ & $31.3 \pm 4.6$ \\
\hline
\end{tabular}

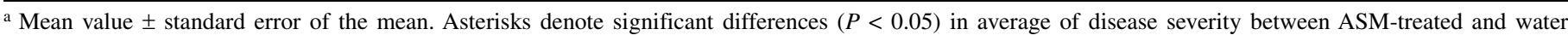
(mock)-treated plants at each experiment at 4 weeks posttreatment, according to Student's $t$ test.

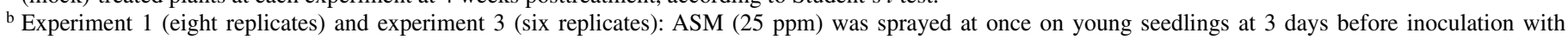
CCYV.

${ }^{\mathrm{c}}$ Experiment 2 (8 replicates) and experiment 4 (16 replicates): ASM (25 ppm) was sprayed at once on young seedlings at 3 days postinoculation with CCYV.

${ }^{\mathrm{d}}$ Experiments 1 to 4 : water was sprayed on young seedlings before or postinoculation with CCYV.

TABLE 3. Disease severity on melon leaves treated with acibenzolar-S-methyl (ASM) postinoculation with Cucurbit chlorotic yellows virus

\begin{tabular}{|c|c|c|c|c|c|c|c|c|c|c|c|c|c|c|c|c|}
\hline \multirow[b]{3}{*}{ Position $^{\mathrm{a}}$} & \multicolumn{16}{|c|}{ Plants ${ }^{b}$} \\
\hline & \multicolumn{8}{|c|}{ ASM-treated replicates } & \multicolumn{8}{|c|}{ Mock-treated replicates } \\
\hline & 1 & 2 & 3 & 4 & 5 & 6 & 7 & 8 & 1 & 2 & 3 & 4 & 5 & 6 & 7 & 8 \\
\hline \multicolumn{17}{|l|}{ Upper } \\
\hline 8 & $\mathbf{0}$ & $\mathbf{0}$ & $\mathbf{0}$ & $\mathbf{0}$ & $\mathbf{0}$ & $\mathbf{0}$ & $\mathbf{0}$ & $\mathbf{0}$ & $\mathbf{0}$ & $\mathbf{0}$ & $\mathbf{0}$ & $\mathbf{0}$ & $\mathbf{0}$ & 1 & $\mathbf{0}$ & $\mathbf{0}$ \\
\hline 7 & $\mathbf{0}$ & $\mathbf{0}$ & $\mathbf{0}$ & $\mathbf{0}$ & $\mathbf{0}$ & 1 & $\mathbf{0}$ & $\mathbf{0}$ & $\mathbf{0}$ & $\mathbf{0}$ & $\mathbf{0}$ & 1 & $\mathbf{0}$ & 1 & $\mathbf{0}$ & $\mathbf{0}$ \\
\hline \multicolumn{17}{|c|}{ Intermediate } \\
\hline 6 & 0 & 0 & 0 & 0 & 0 & 1 & 0 & 0 & 2 & 0 & 1 & 0 & 1 & 1 & 0 & 1 \\
\hline 5 & 0 & 0 & 2 & 0 & 1 & $\mathbf{0}$ & 0 & 0 & 2 & 2 & 0 & 0 & 0 & 1 & 0 & 2 \\
\hline 4 & 0 & 0 & 2 & 1 & 0 & 0 & 0 & 0 & 2 & 3 & 1 & 3 & 2 & 2 & 0 & 4 \\
\hline 3 & 2 & 2 & 4 & 3 & 0 & 0 & 0 & 0 & 3 & 3 & 2 & 3 & 1 & 2 & 2 & 4 \\
\hline \multicolumn{17}{|l|}{ Lower } \\
\hline 2 & 2 & 3 & 3 & 3 & 0 & 0 & 2 & 1 & 3 & 4 & 3 & 4 & 2 & 2 & 1 & 4 \\
\hline 1 & 1 & 4 & 4 & 3 & 3 & 0 & 2 & 2 & 4 & 4 & 3 & 4 & 4 & 4 & 1 & 4 \\
\hline & 15.6 & 28.1 & 46.9 & 31.3 & 12.5 & 6.3 & 12.5 & 9.4 & 50.0 & 50.0 & 31.3 & 46.9 & 31.3 & 43.8 & 12.5 & 59.4 \\
\hline
\end{tabular}

${ }^{\text {a }}$ Leaf samples from lower, intermediate, and upper positions in bold were analyzed by quantitative reverse-transcription polymerase chain reaction in Figure $2 \mathrm{~B}$.

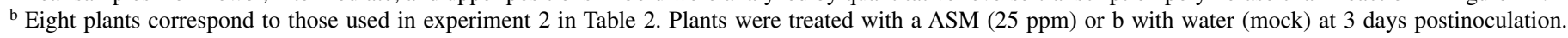
Disease severity (leaf positions 1 to 8 ) was calculated by the formula $\mathrm{D}=\left[\Sigma\left(d_{\mathrm{i}}\right) / n / 4\right] \times 100$, as described in the text. 
inoculation (Fig. 3). Induction of PRla expression was detected in plants treated with $25 \mathrm{~A}$ and $10 \mathrm{~A}$ until 2 and $1 \mathrm{wpt}$, respectively (Fig. 2A). Moreover, levels of PRla expression in lower leaves treated with $25 \mathrm{~A}$ or $10 \mathrm{~A}$ were much higher than those in upper leaves. On the other hand, the levels of PRIa expression in $2.5 \mathrm{~A}$ or mock-treated plants were much lower in the treated and the upper leaves (Fig. 2A). Consistent with lower levels of PRla expression at $4 \mathrm{wpt}$, the $2.5 \mathrm{~A}$-treated plants or the mock-treated plants showed increased accumulation of CCYV (Fig. 2B) and developed typical chlorotic yellows (symptom rate 3 or 4 ) in leaves at lower positions. The 25A- and 10A-treated plants did not show any symptoms or significant levels of virus accumulation at 4 wpt (Fig. 2B). These results suggested that inhibition of initial virus multiplication by treatment with $25 \mathrm{~A}$ or $10 \mathrm{~A}$ was effective in reducing of the disease severity with a lower risk for phytotoxicity.

\section{DISCUSSION}

In this study, we demonstrated that relative levels of the PRla gene expression can be used to monitor the ASM-induced host response and that the ASM-induced antiviral response was effective in reducing severity of CCYV infection and systemic spread in melon.

The previous reports by other research groups suggested that, in general, chemically induced host responses were accompanied by SAR (23). An increase in accumulation of $P R 1$ mRNA is well known as one indicator of SAR $(5,13,27)$. In the present study, the kinetics of the levels of PRla expression suggested that ASMinduced host resistance could be effective at least until $1 \mathrm{wpt}$. This indicated that application of ASM to melon plants every week would be effective in conferring extended protection. Additionally, we found much lower levels of PRla expression in the nontreated fourth upper leaves than those in the ASM-treated first true leaves of melon. These results showed that treatment with ASM also induced local host resistance. ASM may partially or temporally elicit signal transduction pathways associated with SAR.
ASM treatment decreased CCYV accumulation in the treated leaves and attenuated systemic symptoms in melon plants. Treatment with ASM at 3 dbi prevented the plants from becoming systemically infected with CCYV. Therefore, ASM-induced host resistance was triggered in the ASM-treated leaves within 3 days. Most importantly, treatment with ASM at 3 dpi also reduced CCYV accumulation at lower leaves and attenuated symptoms on the plants. The finding again confirmed that the initial level of CCYV in the ASM-treated leaves at an early stage of plant growth mirrors the disease incidence at the late infection stage. Marco et al. (17) reported that RNA of Cucurbit yellow stunting disorder virus (CYSDV; genus Crinivirus, family Closteroviridae) accumulated in older leaves but not in younger leaves during 1 to 2 wpi in susceptible cucurbit plants, including melon. In the present study, CCYV in mock-treated melon plants showed a similar trend (i.e., lower accumulation in younger leaves). Most recently, Okuda et al. (22) also reported lower levels of CCYV in upper leaves of melon. In accordance with the kinetics of virus accumulation, the symptoms of CCYV-infected plants appeared on lower leaves and then slowly spread to intermediate and upper leaves. However, the results indicate that the infection dynamics of CCYV are substantially different from those of CYSDV, because the high level of CYSDV decreased rapidly at 2 wpi. Moreover, the absence or accumulation at much lower levels of CCYV RNA in asymptomatic upper leaves of CCYV-infected melon showed that the rate of CCYV multiplication up to detectable levels is slower than the growth rate of the plants. One possible explanation for the slow rate of CCYV translocation in plants is that CCYV does not express a protein to counteract host basal resistances or RNA silencing (1). In this respect, ASM-induced host resistances can be effective in prevention of extensive invasion of melon plants by CCYV.

Cools and Ishii (4) reported induction of the PRla gene expression in ASM-treated cucumber plants within 3 days. Narusaka et al. $(18,19)$ showed that ASM systemically induced resistance against scab (pathogen: Cladosporium cucumerinum) in cucumber plants and observed rapid accumulation of peroxidase, chitinase,
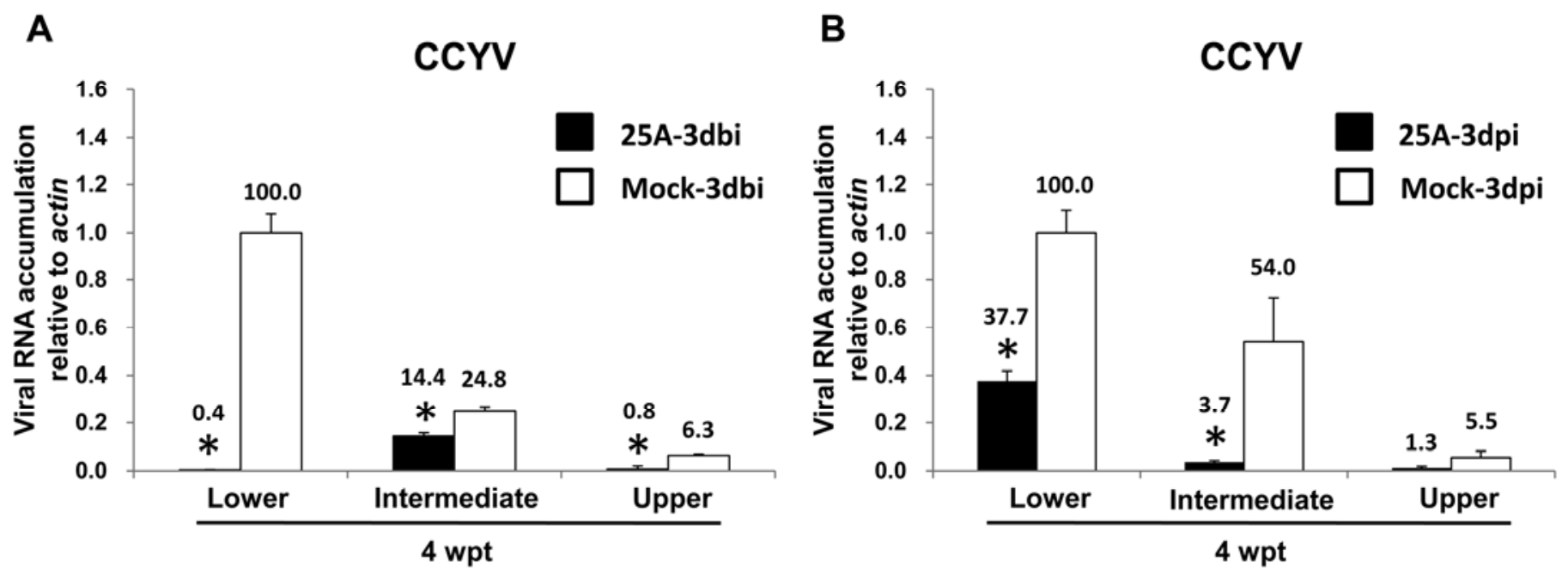

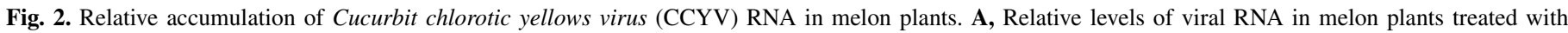

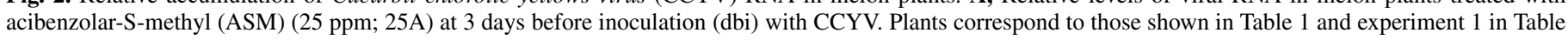

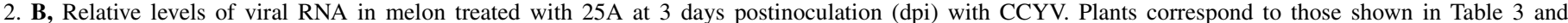

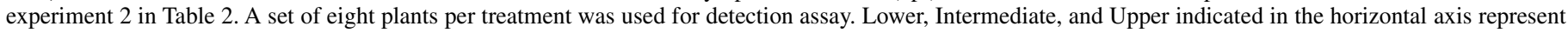

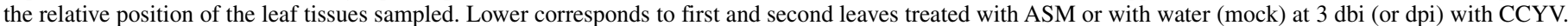

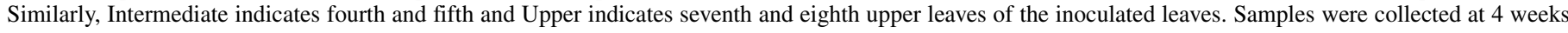

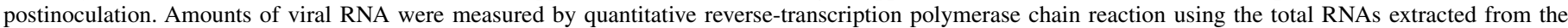

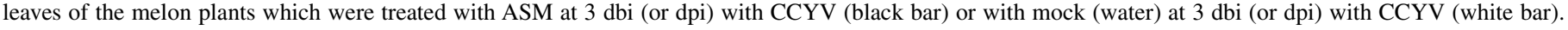

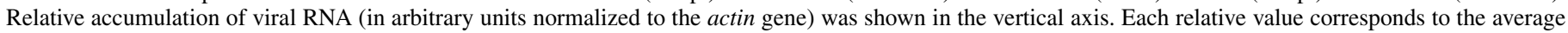

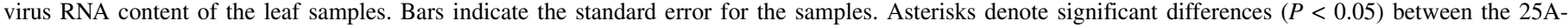

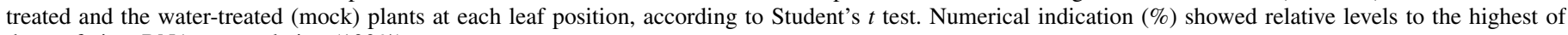
those of virus RNA accumulation (100\%). 
and $\beta$-1,3-glucanase genes. ASM also induced chitinase in cantaloupe seedlings and protected the plants against fungal and viral pathogens (28). Moreover, ASM induced antiviral responses in flue-cured tobacco and successfully restricted replication and movement of Tomato spotted wilt virus (16). As expected, expression of PRla was enhanced in a dose-dependent manner in the ASM-treated melon plants at the early time points after CCYV-inoculations. Furthermore, higher levels of PRla expression were detected in the initially infected plant tissues which were directly sprayed with $10 \mathrm{~A}$ or $25 \mathrm{~A}$. These results indicated that ASM-induced host resistance can reduce CCYV accumulation at the initial infection stage and restrict systemic movement of the virus. Restriction of systemic spread of CCYV might be due to host resistance induced in leaf tissues which are treated with ASM. Furthermore, there could be synergistic effects of ASM treatment on induction of host RNA silencing to reduce CCYV accumulation, because some overlap between SAR and
RNA silencing was suggested by Alamillo et al. (1) and Lewsey and Carr (14).

Appropriate doses may be as essential as the appropriate concentration to avoid ASM-derived phytotoxicity in plants. Successful application of ASM may also depend on the method of ASM treatment, plant growth stage, environmental conditions, or sensitivity of each cultivar. ASM has been examined at different concentrations in various combinations of plants and pathogens $(4,12,15,18,19)$. Optimizing ASM concentration in advance is essential for avoidance of phyotoxicity to investigate the effect of induced resistance to the pathogen. Several lines of evidence obtained from earlier studies suggested appropriate concentrations of ASM for a broad spectrum of crop species $(2,12,15,18,19,28)$. Friedrich et al. (5) reported that substantial resistance in ASMtreated tobacco plants could be induced without hypersensitive responses. The failure in protection of the 2.5A-treated melon against CCYV infection might be due to too low a concentration
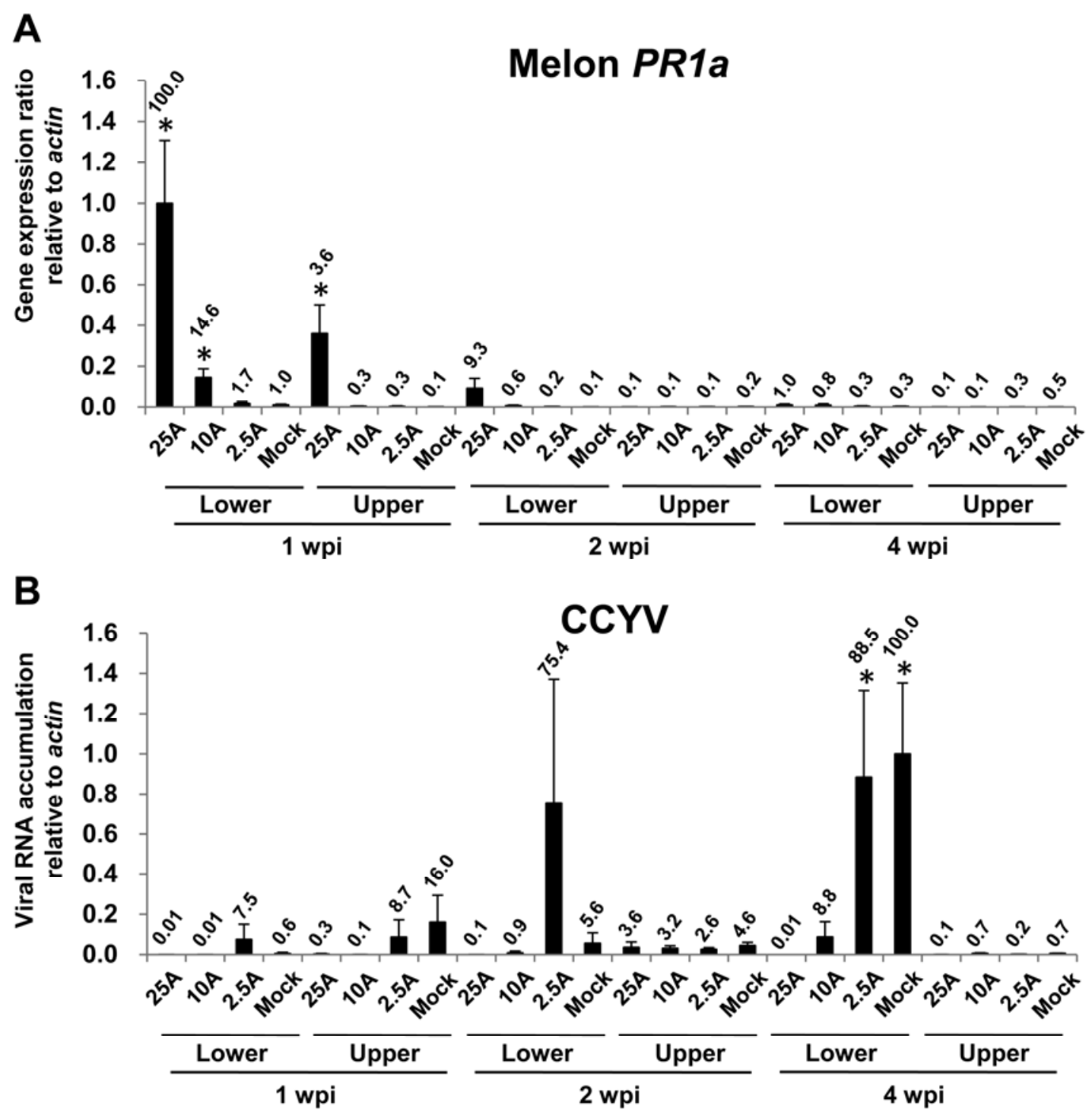

Fig. 3. Relative accumulation levels of the pathogenesis-related $(P R) 1 a$ mRNA and viral RNA in the acibenzolar-S-methyl (ASM)-treated melon plants inoculated with Cucurbit chlorotic yellows virus (CCYV). A, Relative expression levels of the PRla gene in the ASM-treated and -nontreated upper leaf tissues of the melon plants. B, Relative virus RNA levels in the ASM-treated and -nontreated upper leaf tissues of the melon plants. Plants were treated with ASM at a concentration of 25,10 , and $2.5 \mathrm{ppm}(25 \mathrm{~A}, 10 \mathrm{~A}$, and $2.5 \mathrm{~A})$ or with water (mock) at 3 days before inoculation (dbi) with CCYV. Samples were collected at 1,2 , and 4 weeks postinoculation (wpi). Lower indicates first and second leaves treated with ASM at $3 \mathrm{dbi}$. Upper shows third and fourth (1 wpi), fifth and sixth (2 wpi), and eighth and ninth (4 wpi) upper leaves of the inoculated leaves. A set of five plants per treatment was used for detection assay. Asterisks denote significant differences $(P<$ 0.05 ) A, between the $25 \mathrm{~A}, 10 \mathrm{~A}$, or 2.5A-treated and the water-treated (mock) plants or B, between the 10A-, 2.5A-, or water-treated (mock) and the 25A-treated plants at each leaf position at the time point, according to Student's $t$ test. PRla mRNA or viral RNA levels (in arbitrary units) show mean \pm standard error for samples corresponding to the individual plants. Numerical indication (\%) showed relative levels to the highest of those of PR1a gene expression (100\%) and those of virus RNA accumulation (100\%). 
of ASM to trigger the antiviral response. Taken together, we suggest that spraying at concentrations ranging from $10 \mathrm{~A}$ to $25 \mathrm{~A}$ is applicable to melon seedlings at either the first-true-leaf stage or later.

To date, due to the divergence of host-virus interactions among viruses, there are no universal control measures which are effective across different hosts. For practical application, ASM has the potential to become a promising chemical component for inhibition of CCYV infection and should be part of an integrated disease management (IDM) program. As suggested by Nischwitz et al. (20), improved IDM might be achieved by using ASM at late growth stages of melon in combination with application of insecticides at early ones. We suggest that monitoring the PRla gene expression will contribute to establish practical application of ASM. Further studies are needed for estimation of the effects of ASM treatment on induction of resistance to CCYV without any phytotoxicity under field conditions.

\section{ACKNOWLEDGMENTS}

This work was partially funded by Research and Development Projects for Application in Promoting New Policy of Agriculture Forestry and Fisheries, and by a Grant-in-Aid for Scientific Research (24580067) from Japan Society for the Promotion of Science. M. Takeshita and M. Okuda contributed equally to this work. We thank P. Palukaitis for critical reading of this manuscript and suggestions, and Syngenta Japan K. K. for providing ASM.

\section{LITERATURE CITED}

1. Alamillo, J. M., Saénz, P., and García, J. A. 2006. Salicylic acid-mediated and RNA-silencing defense mechanisms cooperate in the restriction of systemic spread of plum pox virus in tobacco. Plant J. 48:217-227.

2. Anfoka, G. 2000. Benzo-(1,2,3)-thiadiazole-7-carbothioic acid $S$-methyl ester induces systemic resistance in tomato (Lycopersicon esculentum Mill cv. Vollendung) to Cucumber mosaic virus. Crop Prot. 19:401-405.

3. Bustin, S. A., Benes, V., Garson, J. A., Hellemans, J., Huggett, J., Kubista, M., Mueller, R., Nolan, T., Pfaffl, M. W. 2009. The MIQE guidelines: Minimum information for publication of quantitative real-time PCR experiments. Clin. Chem. 55:611-622.

4. Cools, H. J., and Ishii, H. 2002. Pre-treatment of cucumber plants with acibenzolar-S-methyl systemically primes a phenylalanine ammonia lyase gene $(P A L 1)$ for enhanced expression upon attack with a pathogenic fungus. Physiol. Mol. Plant Pathol. 61:273-280.

5. Friedrich, L., Lawton, K., Ruess, W., Masner, P., Specker, N., Gut-Rella, M., Meier, B., Dincher, S., Staub, T., Uknes, S., Metraux, J.-P., Kessmann, H., and Ryals, J. 1996. A benzothiadiazole derivative induces systemic acquired resistance in tobacco. Plant J. 10:61-70.

6. Gil, L., Ben-Ari, J., Turgeon, R., and Wolf, S. 2012. Effect of CMV infection and high temperatures on the enzymes involved in raffinose family oligosaccharide biosynthesis in melon plants. J. Plant Physiol. 169:965-970.

7. Gu, Q. S., Liu, Y. H., Wang, Y. H., Huangfu, W. G., Gu, H. F., Xu, L., Song, F. M., and Brown, J. K. 2011. First report of Cucurbit chlorotic yellows virus in cucumber, melon, and watermelon in China. Plant Dis. 95:73.

8. Gyoutoku, Y., Okazaki, S., Furuta, A., Etoh, T., Mizobe, M., Kuno, K., Hayashida, S., and Okuda, M. 2009. Chlorotic yellows disease of melon caused by Cucurbit chlorotic yellows virus, a new crinivirus. Jpn. J. Phytopathol. 75:109-111. (In Japanese with English abstract)

9. Hamed, K., Menzel, W., Dafalla, G., Gadelseed, A. M. A., and Winter, S. 2011. First report of Cucurbit chlorotic yellows virus infecting muskmelon and cucumber in Sudan. Plant Dis. 95:1321.

10. Hanssen, I. M., Lapidot, M., and Thomma, B. P. 2010. Emerging viral diseases of tomato crops. Mol. Plant-Microbe Interact. 23:539-548.

11. Huang, L.-H., Tseng, H.-H., Li, J.-T., and Chen, T.-C. 2010. First report of Cucurbit chlorotic yellows virus infecting cucurbits in Taiwan. Plant Dis. 94:1168.
12. Ishii, H., Tomita, Y., Horio, T., Narusaka, Y., Nakazawa, Y., Nishimura, K., and Iwamoto, S. 1999. Induced resistance of acibenzolar-S-methyl (CGA 245704) to cucumber and Japanese pear diseases. Eur. J. Plant Pathol. 105:77-85.

13. Lawton, K., Friedrich, L., Hunt, M., Weymann, K., Delaney, T., Kessmann, H., Staub, T., and Ryals, J. 1996. Benzothiadiazole induces disease resistance in Arabidopsis by activation of the systemic acquired resistance signal transduction pathway. Plant J. 10:71-82.

14. Lewsey M. G., and Carr, J. P. 2009. Effects of DICER-like proteins 2, 3 and 4 on cucumber mosaic virus and tobacco mosaic virus infections in salicylic acid-treated plants. J. Gen. Virol. 90:3010-3014.

15. Lin, T.-C., and Ishii, H. 2009. Accumulation of $\mathrm{H}_{2} \mathrm{O}_{2}$ in xylem fluids of cucumber stems during ASM-induced systemic acquired resistance (SAR) involves increased LOX activity and transient accumulation of shikimic acid. Eur. J. Plant Pathol. 125:119-130.

16. Mandal, B., Mandal, S., Csinos, A. S., Martinez, N., Culbreath, A. K., and Pappu, H. R. 2008. Biological and molecular analyses of the acibenzolarS-methyl-induced systemic acquired resistance in flue-cured tobacco against Tomato spotted wilt virus. Phytopathology 98:296-204.

17. Marco, C. F., Aguilar, J. M., Abad, J., Gómez-Guillamón, M. L., and Aranda, M. A. 2003. Melon resistance to Cucurbit yellow stunting disorder virus is characterized by reduced virus accumulation. Phytopathology 93:844-852.

18. Narusaka, Y., Narusaka, M., Horio, T., and Ishii, H. 1999. Comparison of local and systemic induction of acquired disease resistance in cucumber plants treated with benzothiadiazoles or salicylic acid. Plant Cell Physiol. 40:388-395.

19. Narusaka, Y., Narusaka, M., Horio, T., and Ishii, H. 1999. Induction of disease resistance in cucumber by acibenzolar-S-methyl and expression of resistance-related genes. Ann. Phytopathol. Soc. Jpn. 65:116-122.

20. Nischwitz, C., Csinos, A. S., Mullis, S. W., Hickman, L. L., Stevenson, K. L., and Gitaitis, R. D. 2008. Effect of transplant age, tobacco cultivar, acibenzolar-S-methyl, and imidacloprid on tomato spotted wilt infection in flue-cured tobacco. Plant Dis. 92:1524-1528.

21. Okuda, M., Okazaki, S., Yamasaki, S., Okuda, S., and Sugiyama, M. 2010. Host range and complete genome sequence of Cucurbit chlorotic yellows virus, a new member of the genus Crinivirus. Phytopathology 100:560-566.

22. Okuda, S., Okazaki, M., Sugiyama, M., Sakata, Y., Takeshita, M., and Iwai, H. 2013. Resistance in melon to Cucurbit chlorotic yellows virus, a whitefly-transmitted crinivirus. Eur. J. Plant Pathol. 135:313-321.

23. Oostendorp, M., Kunz, W., Dietrich, B., and Staub, T. 2001. Induced disease resistance in plants by chemicals. Eur. J. Plant Pathol. 107:19-28.

24. Pappu, H. R., Csinos, A. S., McPherson, R. M., Jones, D. C., and Stephenson, M. G. 2000. Effect of acibenzolar-S-methyl and imidacloprid on suppression of tomato spotted wilt Tospovirus in flue-cured tobacco. Crop Prot. 19:349-354.

25. Pfaffl, M. W., Horgan, G. W., and Dempfle, L. 2002. Relative expression software tool (REST) for group-wise comparison and statistical analysis of relative expression results in real-time PCR. Nucleic Acids Res. 30:e36.

26. Rodríguez-Hernández, A. M., Gosalvez, B., Sempere, R. N., Burgos, L., Aranda M. A., and Truniger, V. 2012. Melon RNA interference (RNAi) lines silenced for Cm-eIF4E show broad virus resistance. Mol. Plant Pathol. 13:755-763.

27. Ryals, J. A., Neuenschwander, U. H., Willits, M. G., Molina, A., Steiner, H. Y., and Hunt, M. D. 1996. Systemic acquired resistance. Plant Cell 8:1809-1819.

28. Smith-Becker, J., Keen, N. T., and Becker, J. O. 2003. Acibenzolar-Smethyl induces resistance to Colletotrichum lagenarium and cucumber mosaic virus in cantaloupe. Crop Prot. 22:769-774.

29. Vandesompele, J., De Preter, K., Pattyn, F., Poppe, B., Van Roy, N., De Paepe, A., and Speleman, F. 2002. Accurate normalization of real-time quantitative RT-PCR data by geometric averaging of multiple internal control genes. Genome Biol. 3:research0034.

30. Wintermantel, W. M. 2004. Emergence of greenhouse whitefly (Trialeurodes vaporariorum) transmitted criniviruses as threats to vegetable and fruit production in North America. American Phytopathological Society, St. Paul, MN. Online publication. doi:10.1094/APSnetFeature2004-0604 